\title{
Defining an Optimum Pumping Time Requirement for Sampling Ground-Water Wells on the Hanford Site
}

\author{
N. L. Scharnhorst
}

April 1982

Prepared for the U.S. Department of Energy under Contract DE-AC06-76RLO 1830

Pacific Northwest Laboratory Operated for the U.S. Department of Energy by Battelle Memorial Institute 


\title{
DISCLAIMER
}

This report was prepared as an account of work sponsored by an agency of the United States Government. Neither the United States Government nor any agency thereof, nor any of their employees, makes any warranty, express or implied, or assumes any legal liability or responsibility for the accuracy, completeness, or usefulness of any information, apparatus, product, or process disclosed, or represents that its use would not infringe privately owned rights. Reference herein to any specific commercial product, process, or service by trade name, trademark, manufacturer, or otherwise, does not necessarily constitute or imply its endorsement, recommendation, or favoring by the United States Government or any agency thereof. The views and opinions of authors expressed herein do not necessarily state or reflect those of the United States Government or any agency thereof.

\author{
PACIFIC NORTHWEST LABORATORY \\ operated by \\ BATTELLE \\ for the \\ UNITED STATES DEPARTMENT OF ENERGY \\ under Contract DE-AC06-76RLO 1830
}

Printed in the United States of America

Available from

National Technical Information Service

United States Department of Commerce

5285 Port Royal Road

Springfield, Virginia 22151

NTIS Price Codes

Microfiche A01

Printed Copy

$\begin{array}{ll}\text { Pages } & \text { Price } \\ \text { Codes }\end{array}$

001-025

026-050

051-075

076-100

101-125

126-150

151-175

176-200

201-225

226-250

251-275

276-300

A06

$\mathrm{A} 07$

A08

A09

A010

A011

A012

A013 
PNL-4192

UC-41

DEFINING AN OPTIMUM PUMPING TIME REQUIREMENT FOR SAMPLING GROUND-WATER WELLS ON THE HANFORD SITE

N. L. Scharnhorst

Apri1 1982

Prepared for

U.S. Department of Energy

Under contract DE-ACO6-76RLO 1830

Pacific Northwest Laboratory

Richland, Washington 99352 


\section{ACKNOWLEDGMENTS}

The author would like to acknowledge the following individuals and their contributions.

- T. E. Barton, L. S. Law, and S. Prestrud contributed to the collection and analysis of field data and also wrote portions of this report.

- G. L. Dirkes, L. S. Prater, C. S. Cline and P. A. Eddy helped with report preparation. 



\section{SUMMARY}

The continuous monitoring of ground water on the Hanford Site is part of the Environmental Monitoring Program conducted by the Pacific Northwest Laboratory (PNL) for the U.S. Department of Energy (DOE). This project was conducted in support of the Environmental Monitoring Program. Data for this study were acquired during the summer months of a four-year period from 1978 through 1981.

The objective of this project was to determine the optimum time period necessary to pump water from a well before a representative sample of the ground water can be obtained. It was assumed that a representative sample has been collected if the concentration of chemical parameters is the same in a number of samples taken consecutively, so that the concentration of parameters does not vary with time of collection.

Ground-water samples used in this project were obtained by pumping selected wells on the Hanford Site. At each well, samples were taken at two minute intervals, and on each sample various chemical analyses were performed. During the summer of 1978, samples were checked for $\mathrm{pH}$, sulfate, iron and specific conductivity. During the summers of 1979 and 1980, this 1 ist of analyses was expanded to include tests for chloride, nitrate and alkalinity. During the summer of 1981 , specific conductivity was dropped from the list of tests conducted.

The data showed that pH, alkalinity, sulfate and specific conductivity levels stabilized almost immediately after pumping of the well began. In many wells, the chloride and nitrate levels were unstable throughout the 38-minute sampling period. Iron levels, however, did not behave in either fashion. The concentration of iron in the samples was high when pumping began but dropped rapidly as pumping continued. The best explanation for this is that iron is flushed from the sides of the casing into the well when pumping begins. After several minutes of pumping, most of the dissolved iron is washed from the well casing and the iron concentration reaches a stable plateau representative of the iron concentration in the ground water. Since iron concentration takes longest to stabilize, the 
optimum pumping time for a well is based on the iron stabilization time for that we11. In this project the length of time required for the iron content to stabilize varied from well to well. Therefore, a unique optimum pumping time was determined for each of the 111 wells tested. 


\section{CONTENTS}

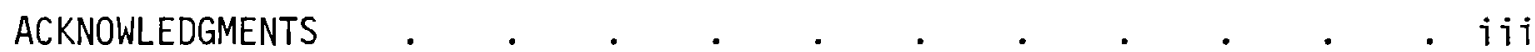

SUMMARY . . . . . . . . . . . . . . . . . . . . .

INTRODUCTION

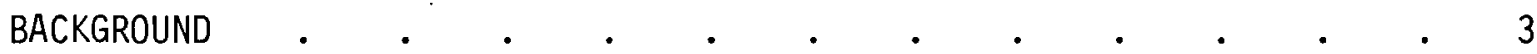

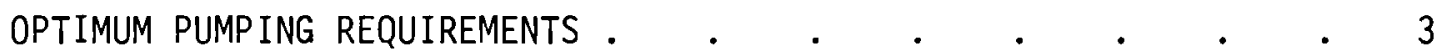

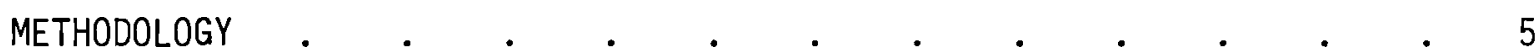

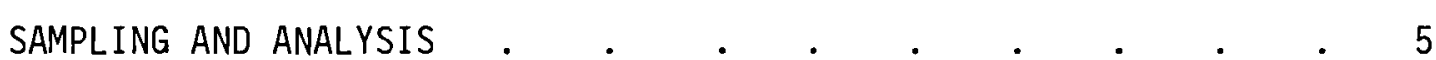

EVALUATION AND PRESENTATION OF DATA . . . . . . . . 5

RESULTS

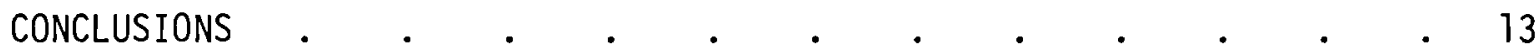

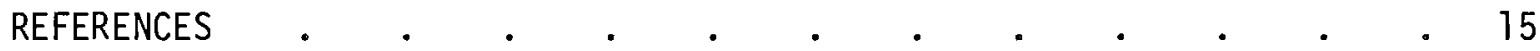

APPENDIX A--ANALYTICAL PROCEDURES •

APPENDIX B--ANALYSIS OF WELL NUMBER 699-55-50C $. \quad . \quad . \quad . \quad . \quad . \quad$ B. 1

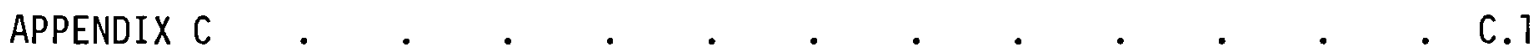




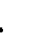




\section{FIGURES}

1 Locations of Wells on the Hanford Site . . . . . 2

B.1 The pH vs. Pumping Time in Well 699-55-50C . . . . B.2

B.2 $\mathrm{CaCO}_{3}$ Concentration vs. Pumping Time in Well 699-55-50C • . B.2

B.3 Chloride Concentration vs. Pumping Time in Well 699-55-50C . B.3

B.4 Nitrate Concentration vs. Pumping Time in Well 699-55-50C . B.3

B.5 Iron Concentration vs. Pumping Time in We11 699-55-50C . . B.4

B.6 Sulfate Concentration vs. Pumping Time in Well 699-55-50C . B.4

B.7 Specific Conductivity vs. Pumping Time in Well 699-55-50C . B.5

C.1 Chloride Standard Curve . . . . . . . . . C.1

C.2 Nitrate Standard Curve . . . . . . . . . C.2

$\underline{\text { TABLES }}$

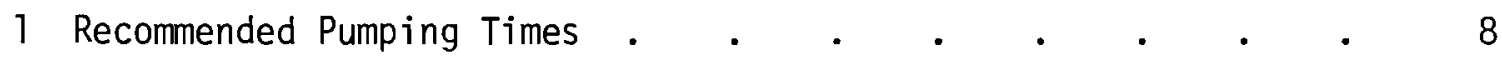

B.1 Recommended Pumping Times for We11 699-55-50C . . . . B.1 
DEFINING AN OPTIMUM PUMPING TIME REQUIREMENT FOR

SAMPLING GROUND-WATER WELLS ON THE HANFORD SITE

\section{INTRODUCTION}

The Environmental Monitoring Program of the Hanford Site was designed to determine how contamination produced from the operations onsite moves to the environment. The Environmental Monitoring Program is conducted by the Pacific Northwest Laboratory (PNL) for the U.S. Department of Energy (DOE). One section of this comprehensive study is the Ground-Water Monitoring Program. This program records the movement of chemical and radioactive contamination through the unconfined aquifer beneath the Hanford Site. Three tracers (beta, tritium and nitrate) are the primary species monitored. The purpose of this particular project was to determine how long the wells on the Hanford Site must be pumped before representative water samples can be obtained. Figure 1 is a map showing the locations of the monitoring wells on the Hanford Site. A11 ground-water samples used for this project were obtained and anaiyzed by PNL's Environmental Evaluations Section of the Occupational and Environmental Protection Department. 


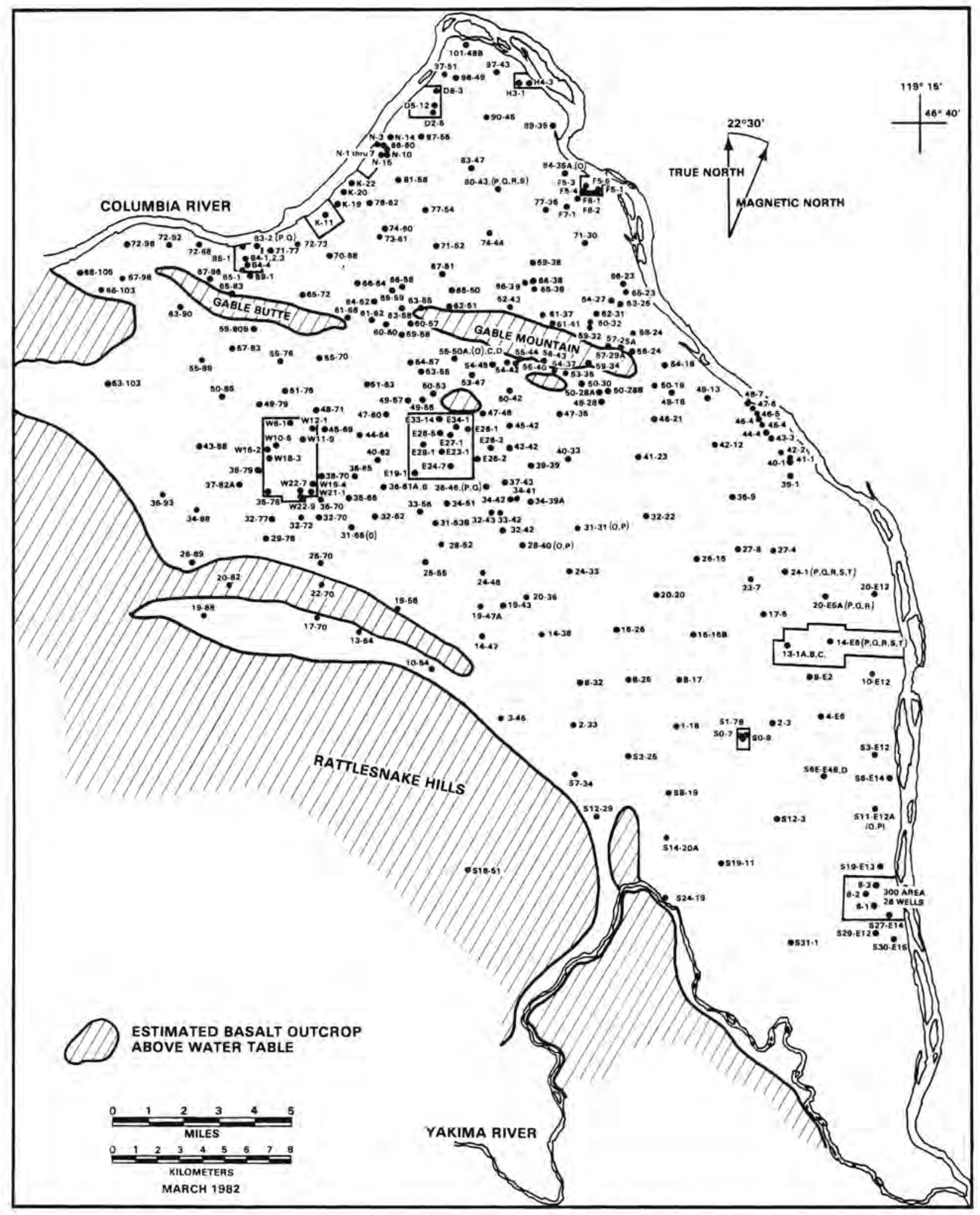

FIGURE 1. Locations of Wells on the Hanford Site 


\section{BACKGROUND}

In the Ground-Water Monitoring Program, ground water from a network of wells on the Hanford Site is routinely sampled and analyzed. Three hundred and seventeen wells were sampled by PNL for the 1980 monitoring program. In this particular project, 111 wells were tested. According to the sampling procedures guide, PNL-MA-580 (Occupational and Environmental Safety Department 1978), the wells must be pumped for an arbitrary time of 15 minutes before a sample is taken. Previous to this project, no quality assurance tests have been done on this 15-minute discharging requirement.

\section{OPTIMUM PUMPING REQUIREMENTS}

The objective of this project was to determine the optimum pumping time required before a representative water sample can be obtained from a well. Each well has a unique optimum pumping time requirement. The three major contributors to the pumping requirement are the length of the well casing in contact with the saturated portion of the aquifer, the flow rate and the chemical parameter under consideration. The well casing is one of the sources of impurities in the well water. Therefore, both the length of the well casing in contact with the saturated portion of the aquifer and the flow rate are important because they affect the amount of time that the ground water is in contact with the well casing. The type of chemical parameter being measured is important because some chemicals will interact with the well casing, causing a change in the sample concentrations.

Chemical interactions with the well casing can be of several types. Chemicals such as iron which are constituents of the pipe may be dissolved. Dissolution of iron from the casing artificially raises the iron concentration in the water until the casing is flushed out. Conversely, adsorption or ion exchange on the pipe can lower the concentration of a chemical in the water. Another factor that possibly affects the concentration of chemical parameters is the change in pressure or temperature of the ground water upon release from the aquifer. Carbonate, measured as alkalinity, leaves solution in gaseous form as carbon dioxide when the pressure is decreased. Nitrate leaves solution in gaseous form when the temperature is increased. 
As a result of the different considerations, each well has a unique pumping requirement. Thus, by first determining the pumping requirement for each constituent in the well it is possible to calculate the overall pumping requirement. The longest of the individual pumping requirements is used for the overall requirement in crder to ensure that a completely representative sample of the ground water is collected. 


\section{METHODOLOGY}

SAMPLING AND ANALYSIS

This project was carried out by conducting chemical analyses on a series of water samples collected from various wells. Parameters analyzed were pH, alkalinity, chloride, nitrate, iron, sulfate and specific conductivity. A mobile laboratory was used to avoid delays in analyzing the samples.

The particular series of chemical analyses used were chosen primarily for ease of analysis and availability of equipment. Tests for iron, sulfate and specific conductivity were conducted during the first three summers using a HACH DR-EL/2 kit. During the fourth summer, a HACH DR/1 kit was used. The $\mathrm{pH}$ and alkalinity tests were made with a Beckman Model GS Field pH meter. Nitrate and chloride concentrations were measured by specific ion probes attached to the Beckman meter and were read on the millivolt scale. In this capacity, the Beckman meter became a potentiometer. The exact procedures for conducting analyses with this equipment are given in Appendix $A$ of this report. In the actual pumping of the wells, samples were taken at two minute intervals. At each well, the first sample was taken as soon as the well began discharging and timing began at that point. In this fashion, samples were taken for 38 minutes. A total of 20 samples was collected at each well.

EVALUATION AND PRESENTATION OF DATA

In order to evaluate the data obtained, graphs were constructed relating concentration of each chemical parameter to time. (See Appendix B for an example of the graphs.) The curves were drawn to show a general trend and were not intended to be best-fit curves. Recommendations as to the optimum pumping time of a well were then made by analyzing the results of all of the tests on that particular well. The recommendations made were based on the following assumptions:

- The water from the well is representative of the ground water at the time when the graph shows chemical stability. Chemical stability is represented by a flat line or band (given analytical error) on the graph. 
- The total volume of water pumped is a critical factor. (A well pumped at half of the discharge rate will take twice as long to reach the same chemical stability.) 


\section{RESULTS}

The data obtained from the $\mathrm{pH}$, alkalinity, sulfate and specific conductivity tests almost never varied with pumping time. This indicates that in general, the concentrations of these parameters were not affected by interactions with the well casing. A sample taken after any amount of pumping should have a $\mathrm{pH}$, alkalinity, sulfate or specific conductivity level representative of the ground water. The rare exceptions to this rule were isolated cases and may be due to experimental error.

In the chloride and nitrate tests, many instances of unstable behavior were found. Due to the sensitivity of these probes to temperature and the harsh conditions (i.e., extreme heat) under which they were operated, many of these data have to be evaluated very subjectively. Therefore, stabilization of chloride and nitrate levels was not considered to be a primary factor in the determination of optimum pumping time requirements.

In the iron tests, the concentration of the iron was found to be extremely high in the first few minutes of pumping. The best explanation for this is that iron is flushed from the sides of the well casing when pumping begins. After several minutes of pumping, most of the dissolved iron is washed from the well casing and the iron concentration reaches a stable plateau representative of the iron concentration in the ground water. The volume of water required to reach this stabilization is different for every well, therefore each well has a unique optimum pumping time.

A list of recommended pumping times for the 111 wells tested is given in Table 1. 
TABLE 1. Recommended Pumping Times

\begin{tabular}{|c|c|c|}
\hline We11 Number & $\begin{array}{l}\text { Recommended } \\
\text { Pumping Time } \\
\text { (minutes) }\end{array}$ & $\frac{\text { Flow Rate }}{\text { (gallons/minute) }}$ \\
\hline 399-1-1 & 22 & 5.0 \\
\hline $399-2-1$ & 14 & 6.9 \\
\hline $699-2-7$ & * & 3.2 \\
\hline $399-3-1$ & 4 & 9.5 \\
\hline $699-8-17$ & 16 & 5.0 \\
\hline $699-8-25$ & 14 & 7.5 \\
\hline $699-11-45 A$ & 8 & 41.0 \\
\hline $699-15-15 B$ & 16 & 10.7 \\
\hline 699-15-E13 & 7 & 15.1 \\
\hline $699-19-43$ & * & 6.8 \\
\hline $699-20-20$ & $\star$ & 10.0 \\
\hline $699-20-39$ & 16 & 9.4 \\
\hline $699-22-70$ & 16 & 10.0 \\
\hline $699-24-33$ & 10 & 8.3 \\
\hline $699-25-80$ & $\star$ & 9.4 \\
\hline $699-26-15$ & 4 & 10.0 \\
\hline $699-27-08$ & 10 & 5.3 \\
\hline $699-28-40$ & 14 & 8.3 \\
\hline $699-31-31$ & $10-20$ & 8.8 \\
\hline $699-32-43$ & 4 & 10.0 \\
\hline $699-32-70$ & 2 & 8.3 \\
\hline $699-32-72$ & 22 & 6.8 \\
\hline $699-33-42$ & 10 & 7.5 \\
\hline $699-34-39 A$ & * & 6.8 \\
\hline $699-34-42$ & 6 & 7.9 \\
\hline $699-35-27$ & 20 & 2.6 \\
\hline $699-35-66$ & 14 & 4.6 \\
\hline
\end{tabular}

* An optimum pumping time could not be determined with the available data. 
TABLE 1. Recommended Pumping Times (Cont'd.)

\begin{tabular}{|c|c|c|}
\hline Well Number & $\begin{array}{r}\begin{array}{r}\text { Recommended } \\
\text { Pumping Time }\end{array} \\
\text { (minutes) }\end{array}$ & $\frac{\text { Flow Rate }}{\text { (gallons/minute) }}$ \\
\hline $699-36-61 A$ & 14 & 6.8 \\
\hline $699-37-43$ & 14 & 4.3 \\
\hline $699-38-65$ & 10 & 9.4 \\
\hline $699-38-70$ & 8 & 1.2 \\
\hline $699-40-1$ & 20 & 220.0 \\
\hline $699-40-33$ & $10-20$ & 5.6 \\
\hline $699-40-62$ & 6 & 3.7 \\
\hline $699-42-12$ & 20 & 2.9 \\
\hline $699-44-64$ & 8 & 6.5 \\
\hline $699-46-21$ & 7 & 35.0 \\
\hline $699-47-35 A$ & $\star$ & 5.0 \\
\hline $699-47-46$ & 24 & 2.0 \\
\hline $699-47-60$ & 18 & 11.5 \\
\hline $699-48-18$ & 8 & 6.4 \\
\hline $699-48-71$ & 8 & 1.8 \\
\hline $699-49-55$ & 10 & 0.4 \\
\hline $699-49-57$ & $\star$ & 2.5 \\
\hline $699-49-79$ & 14 & 10.7 \\
\hline $699-50-28 B$ & 14 & 7.5 \\
\hline $699-50-42$ & 20 & 12.5 \\
\hline $699-50-53$ & 14 & 7.5 \\
\hline $699-50-85$ & 12 & 7.5 \\
\hline $699-51-63$ & 20 & 3.3 \\
\hline $699-51-75$ & 22 & 12.5 \\
\hline $699-52-52$ & 36 & 1.3 \\
\hline $699-53-47$ & 40 & 1.6 \\
\hline $699-53-55 A$ & 20 & 4.8 \\
\hline
\end{tabular}

* An optimum pumping time could not be determined with the available data. 
TABLE 1. Recommended Pumping Time (Cont'd.)

\begin{tabular}{|c|c|c|}
\hline We11 Number & $\begin{array}{l}\text { Recommended } \\
\text { Pumping Time } \\
\text { (minutes) }\end{array}$ & $\frac{\text { Flow Rate }}{\text { (gallons/minute) }}$ \\
\hline $699-54-57$ & 20 & 5.8 \\
\hline $699-55-50 c$ & 20 & 8.8 \\
\hline $699-55-76$ & 40 & 7.1 \\
\hline $699-55-89$ & 34 & 5.4 \\
\hline $699-57-25 A$ & 8 & 11.5 \\
\hline $699-57-29 A$ & 6 & 10.0 \\
\hline $699-57-83$ & $\star$ & 6.8 \\
\hline $699-59-32$ & 12 & 6.0 \\
\hline $699-59-58$ & 14 & 6.7 \\
\hline $699-60-32$ & 18 & 10.0 \\
\hline $699-60-57$ & 16 & 8.5 \\
\hline $699-61-37$ & 18 & 8.6 \\
\hline $699-61-41$ & 16 & 5.5 \\
\hline $699-61-62$ & 12 & 7.9 \\
\hline $699-61-66$ & 16 & 7.5 \\
\hline $699-62-31$ & 14 & 6.0 \\
\hline $699-62-43 F$ & 20 & 11.1 \\
\hline $699-62-57$ & 20 & 4.6 \\
\hline $699-63-55$ & 22 & 10.0 \\
\hline $699-63-58$ & 18 & 5.8 \\
\hline $699-64-27$ & 14 & 15.0 \\
\hline $699-64-62$ & 12 & 6.4 \\
\hline $699-65-50$ & 12 & 6.0 \\
\hline $699-65-59 A$ & 10 & 7.5 \\
\hline $699-65-72$ & 20 & 7.5 \\
\hline $699-65-83$ & $\star$ & 7.9 \\
\hline $699-66-39$ & * & 12.0 \\
\hline
\end{tabular}

* An optimum pumping time could not be determined with the available data. 
TABLE 1. Recommended Pumping Time (Cont'd.)

\begin{tabular}{|c|c|c|}
\hline We11 Number & $\begin{array}{l}\text { Recommended } \\
\text { Pumping Time } \\
\text { (minute) }\end{array}$ & $\frac{\text { Flow Rate }}{\text { (gallons/minute) }}$ \\
\hline $699-66-58$ & 28 & 8.5 \\
\hline $699-66-64$ & 12 & 7.7 \\
\hline $699-67-51$ & 40 & 3.1 \\
\hline $699-67-86$ & 12 & 5.0 \\
\hline $699-67-98$ & 20 & 4.5 \\
\hline $699-71-30$ & 8 & 8.6 \\
\hline $699-71-52$ & 26 & 6.7 \\
\hline $699-71-77$ & 18 & 8.8 \\
\hline $699-72-73$ & 20 & 7.5 \\
\hline $699-74-60$ & 12 & 8.5 \\
\hline $699-77-36$ & 18 & 10.0 \\
\hline $699-77-54$ & 16 & 3.8 \\
\hline $699-78-62$ & 12 & 1.3 \\
\hline $699-81-58$ & 20 & 6.5 \\
\hline $699-87-55$ & 14 & 2.5 \\
\hline $699-90-45$ & 24 & 2.3 \\
\hline $699-96-49$ & 24 & 2.7 \\
\hline $699-97-43$ & 12 & 18.8 \\
\hline $699-97-51 \mathrm{~A}$ & $\star$ & 6.0 \\
\hline $699-101-48 B$ & 18 & 15.0 \\
\hline 699-HAN-6 & 11 & 10.0 \\
\hline 199-H3-1 & 9 & 75.0 \\
\hline $199-\mathrm{H} 4-3$ & 22 & unknown \\
\hline $699-53-25$ & 12 & 10.0 \\
\hline 699-S6-E4D & 15 & 8.6 \\
\hline $699-58-19$ & 8 & 8.8 \\
\hline
\end{tabular}

* An optimum pumping time could not be determined with the available data. 
TABLE 1. Recommended Pumping Time (Cont'd.)

\begin{tabular}{|c|c|c|}
\hline Well Number & $\begin{array}{l}\text { Recommended } \\
\text { Pumping Time } \\
\text { (minutes) }\end{array}$ & $\frac{\text { Flow Rate }}{\text { (gallons/minute) }}$ \\
\hline $699-\$ 16-24$ & $2-22$ & 3.0 \\
\hline 699-S18-E2B & 10 & 110.0 \\
\hline 699-S19-E11 & 12 & 10.0 \\
\hline 699-S19-E13 & 7 & 10.0 \\
\hline
\end{tabular}




\section{CONCLUSIONS}

For some wells on the Hanford Site, the present 15-minute pumping requirement prior to sampling is not sufficient for obtaining a representative ground-water sample. The seven chemical parameters studied can be divided into three groups on the basis of stabilization behavior. One group, composed of $\mathrm{pH}$, alkalinity, sulfate and specific conductivity, is characterized by rapid stabilization of concentration level. A second group, composed of nitrate and chloride, is characterized by a lack of stabilization throughout the 38-minute sampling period. A third group, composed of iron alone, is characterized by slow stabilization. Iron concentration often did not stabilize until large volumes of water were pumped from the wells. Each well's optimum pumping time was generally determined according to the time required for stabilization of the iron concentration. Table 1 shows the recommended optimum pumping time for the 111 wells tested.

The findings of this effort call for an extension of this project. The project will not be completed until an optimum pumping time has been established for the remainder of the 317 routinely sampled wells on the Hanford Site. 


\section{REFERENCES}

1. Occupational and Environmental Safety Department. 1978. Environmental Monitoring Procedures. PNL-MA-580, Pacific Northwest Laboratory, Richland, Washington. 
APPENDIX A

ANALYTICAL PROCEDURES 
APPENDIX A

ANALYTICAL PROCEDURES

Note: In order to duplicate the procedures used in this project, samples should be taken at 2-minute intervals from 9 to 38 minutes for a total of 20 samples.

\section{PH AND ALKALINITY}

Note: The tests used to determine $\mathrm{pH}$ and alkalinity are combined into one procedure for ease and efficiency.

Equipment: Beckman Model GS Field pH Meter, Combination pH Electrode, battery operated magnetic stir box, standard $\mathrm{HNO}_{3}$ solution, burette, graduated cylinder, 20 beakers, thermometer.

Procedure:

1) Insert the electrode into the meter. Standardize the meter by placing the electrode in a pH 4.0 buffer solution. After setting the temperature compensator knob to the temperature buffer, turn the zero adjuster until the meter reads 4.0. Check the accuracy of the electrode and meter by rinsing the electrode with distilled water and placing it in a pH 7.0 buffer. Record any deviation from 7.0.

2) Place a $50 \mathrm{~m} \ell$ sample and the electrode into the beaker. Using the magnetic stir box, record the $\mathrm{pH}$ when the reading stabilizes.

3) For alkalinity, add standardized $\mathrm{HNO}_{3}$ slowly from the burette until the $\mathrm{pH}$ reaches 4.5. Record the volume of acid needed to reach 4.5.

4) Calculate the concentration of $\mathrm{CaCO}_{3}$ (alkalinity) by using the following equation:

$$
\frac{A \times N \times 50,000}{S}=\mathrm{CaCO}_{3} \text { concentration }
$$

where:

$A=$ volume of acid added

$\mathrm{N}=$ normality of acid 
$S=$ volume of sample

$50,000 \mathrm{mg}=50 \mathrm{~g} \mathrm{CaCO}_{3}$ (1 equivalent weight)

5) Rinse the electrode with distilled water before each use and store it in a $\mathrm{pH} 4.0$ buffer when not in use.

Note: Samples should be tested for $\mathrm{pH}$ and alkalinity as soon as possible after collection.

\section{NITRATE - NITROGEN}

Equipment: Beckman Model GS Field pH Meter, Orion Nitrate Sensing Electrode and double junction reference electrode, battery operated magnetic stir box, graduated cylinder, 20 beakers.

Procedure:

1) Depress the +mv button and prepare the electrodes for operation. Place the electrodes into a $50 \mathrm{me}$ sample, start the magnetic stir box, and record the reading on the potentiometer upon stabilization.

2) Rinse the electrodes before each use with distilled water.

3) Store the reference electrode in distilled water and store the Nitrate Sensing Electrode in air when not in use.

4) Determine the actual nitrate concentration by referring to a standard curve. (See Appendix C for an example.)

\section{CHLORIDE}

Equipment: Beckman Model GS Field pH Meter, Orion Combination Chloride Electrode, graduated cylinder, 20 beakers.

Procedure:

1) Depress the +mv button and prepare the electrode for operation. Place the electrode into a 50 me sample and while swirling, record the reading on the potentiometer upon stabilization.

2) Rinse the electrode before each use with distilled water. 
3) Store the electrode in distilled water when not in use.

4) Determine the actual chloride concentration by referring to a standard curve. (See Appendix C for example.)

Note: Do not use magnetic stir bar for this test.

\section{SPECIFIC CONDUCTIVITY}

Equipment: HACH DR-EL/2 kit with specific conductivity electrode, graduated cylinder, 20 beakers.

Procedure:

1) Insert electrode in 50 me sample. Stir vigorously to remove air bubbles from electrode. Record conductivity upon stabilization.

2) Rinse the electrode before each use with distilled water.

3) Store the electrode in air when not in use.

$\underline{\text { IRON }}$

Equipment: HACH DR-EL/2 or HACH DR/l kit, graduated cylinder, 80 Erlenmeyer Flasks.

Procedure:

1) Measure three $25 \mathrm{ml}$ aliquots from each sample into three clean Erlenmeyer flasks.

2) Add the contents of HACH Ferro Ver Powder Pillow to each flask. Swirl to mix. The color must develop for two minutes, but not more than ten.

3) Turn the wavelength dial to $500 \mathrm{~nm}$. Place the iron scale card in the meter.

4) Fill a clean 25 me sample cell with the original water sample. Place in the cell holder. Adjust the light control to obtain a meter reading of zero.

5) Empty the cell and fill with one of the three prepared samples (from Step 2). Place in the cell holder. Record the $\mathrm{mg} / \mathrm{l}$ of total iron. 
6) Rinse cell with distilled water between tests.

Note: Be careful not to touch the sides of the cell. The HACH kit is a spectrophotometer and is therefore sensitive to light. It records the light that passes through the sample.

\section{SULFATE}

Equipment: HACH DR-EL/2 or HACH DR/1 kit, graduated cylinder, 80 Erlenmeyer Flasks.

Procedure:

1) Measure three $25 \mathrm{ml}$ aliquots from each sample into three clean Erlenmeyer flasks.

2) Add the contents of a HACH Sulfa Ver IV Powder Pillow to each flask. Swirl to mix. The color must develop for five minutes, but not more than fifteen.

3) Turn the wavelength dial to $450 \mathrm{~nm}$. Place the sulfate scale card on the meter.

4) Fill a clean 25 me sample cell with the original water sample. Place in the cell holder. Adjust the light control to obtain a meter reading of zero.

5) Empty the cell and fill with one of the three prepared samples (from Step 2). Place in the cell holder. Record the $\mathrm{mg} / \ell$ of sulfate.

6) Rinse cell with distilled water between tests.

Note: Be careful not to touch the sides of the cell. The HACH kit is a spectrophotometer and is therefore sensitive to light. It records the amount of light that passes through the sample. 
APPENDIX B

ANALYSIS OF WELL NUMBER 699-55-50C 
APPENDIX B

ANALYSIS OF WELL NUMBER 699-55-50C

This appendix contains graphs for well number 699-55-50C. In each graph, the concentration of a parameter is plotted against pumping time. Stabilization is reached when the curve flattens. Recommended pumping times determined by analysis of these graphs are presented in Table B-1.

TABLE B-1. Recommended Pumping Times for We11 Number 699-55-50C

Figure Number Constituent Tested For Recommended Pumping Time

B-1 $\mathrm{pH}$

4 minutes

B-2

Alkalinity $\left(\mathrm{CaCO}_{3}\right)$

4 minutes

B-3

Chloride

4 minutes

B-4

Nitrate

10 minutes

B-5

Iron

20 minutes

B-6

Sulfate

8 minutes

B-7

Specific Conductivity

4 minutes

The overa 11 recommended pumping time requirement is 20 minutes at 8.8 gallons/minute.

B. 1 


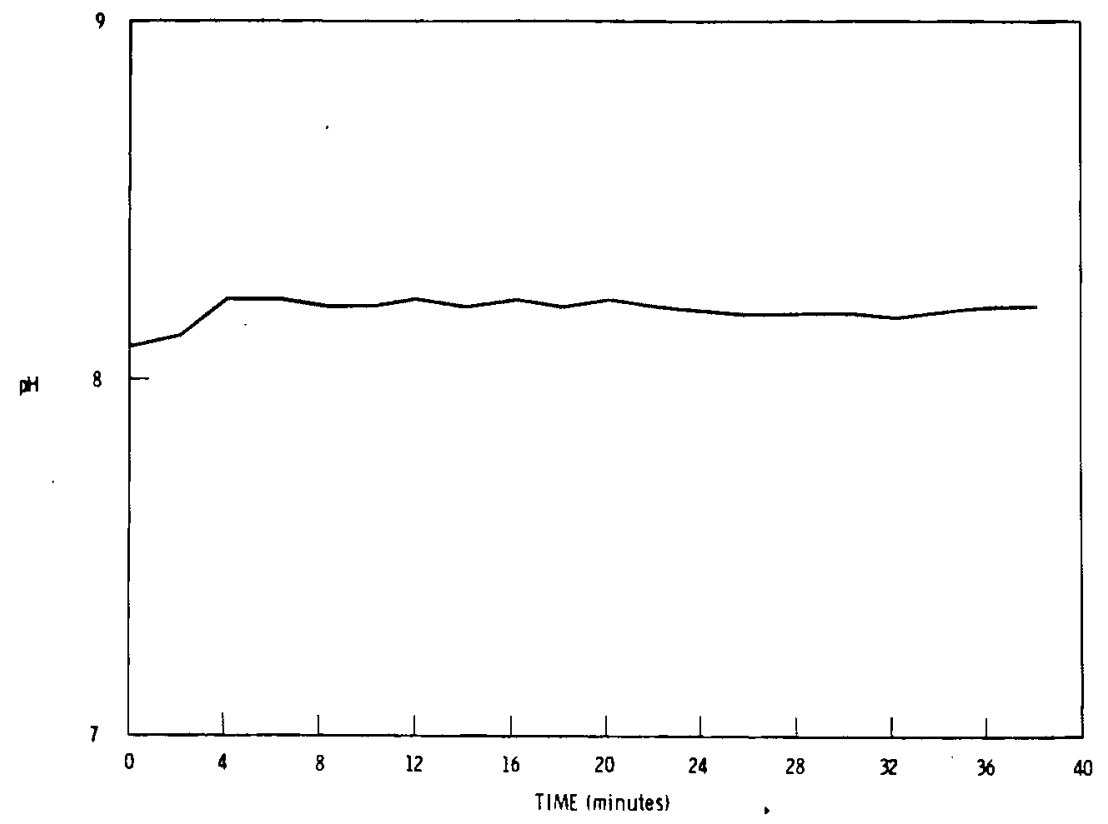

FIGURE B.1. The pH vs. Pumping Time in We11 699-55-50C

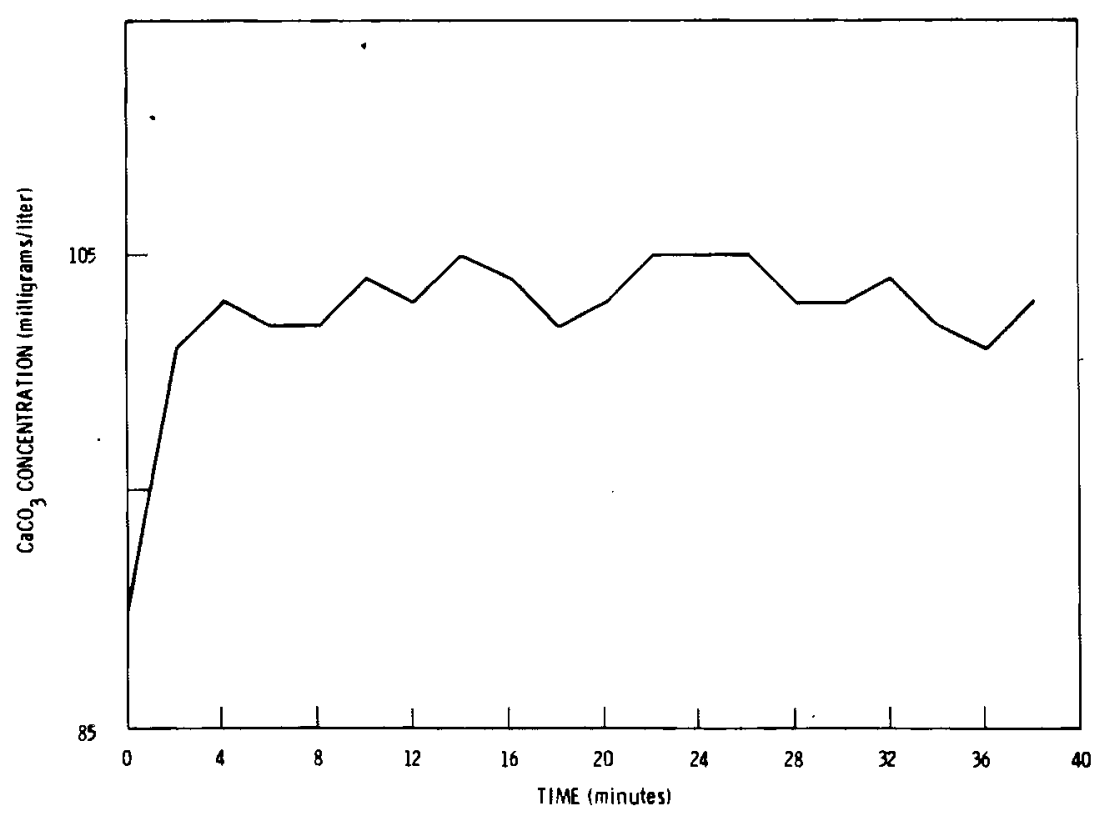

FIGURE B.2. $\mathrm{CaCO}_{3}$ Concentration vs. Pumping Time in Well 699-55-50C 


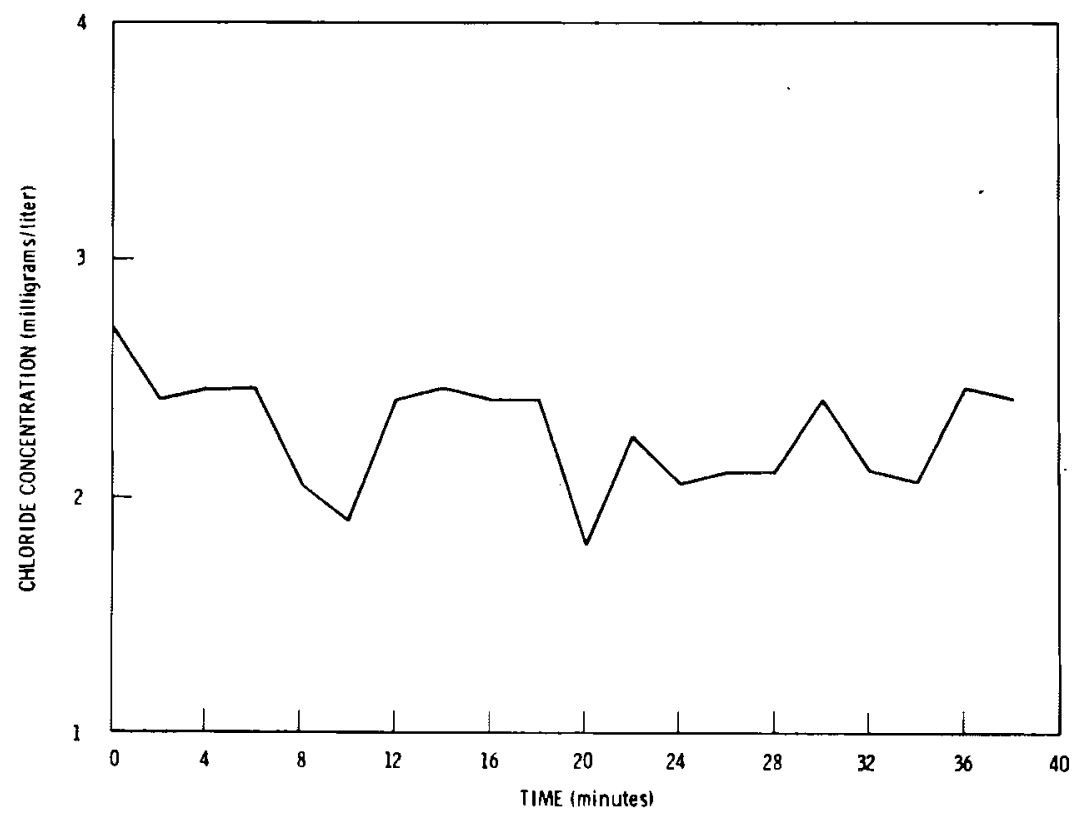

FIGURE B.3. Chloride Concentration vs. Pumping Time in Well 699-55-50C

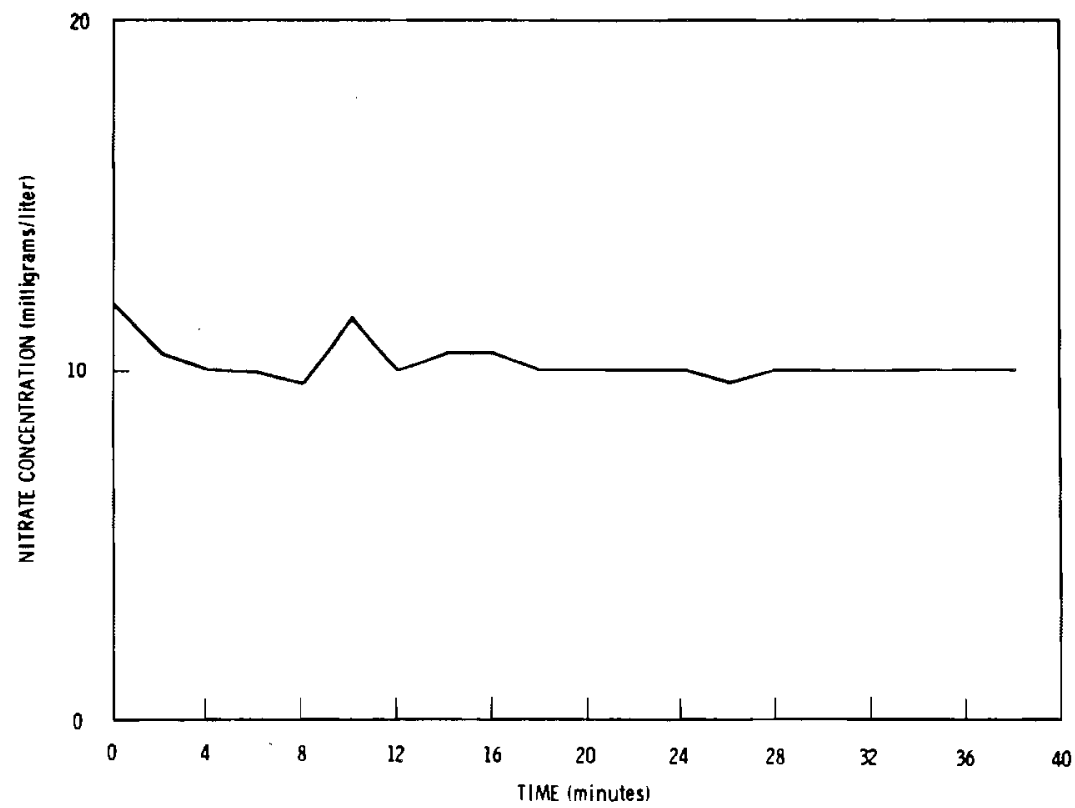

FIGURE B.4. Nitrate Concentration vs. Pumping Time in Well 699-55-50C

B. 3 


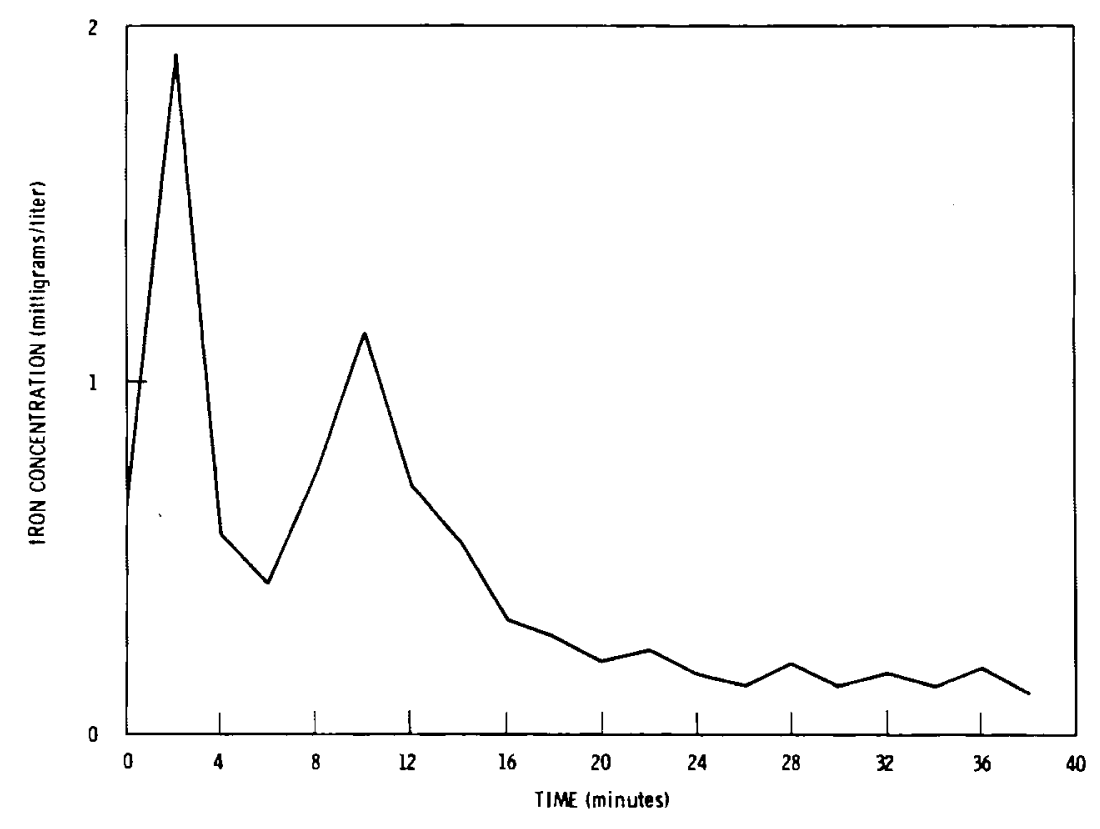

FIGURE B.5. Iron Concentration vs. Pumping Time in Well 699-55-50C

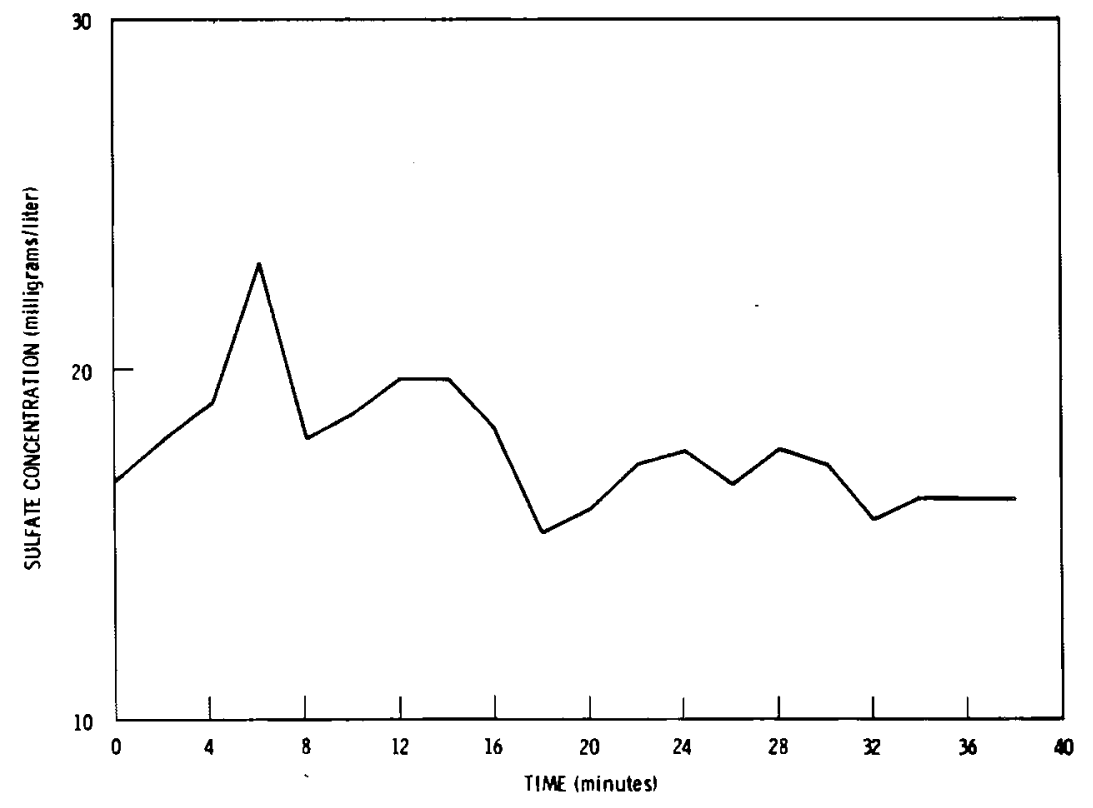

FIGURE B.6. Sulfate Concentration vs. Pumping Time in Well 699-55-50C 


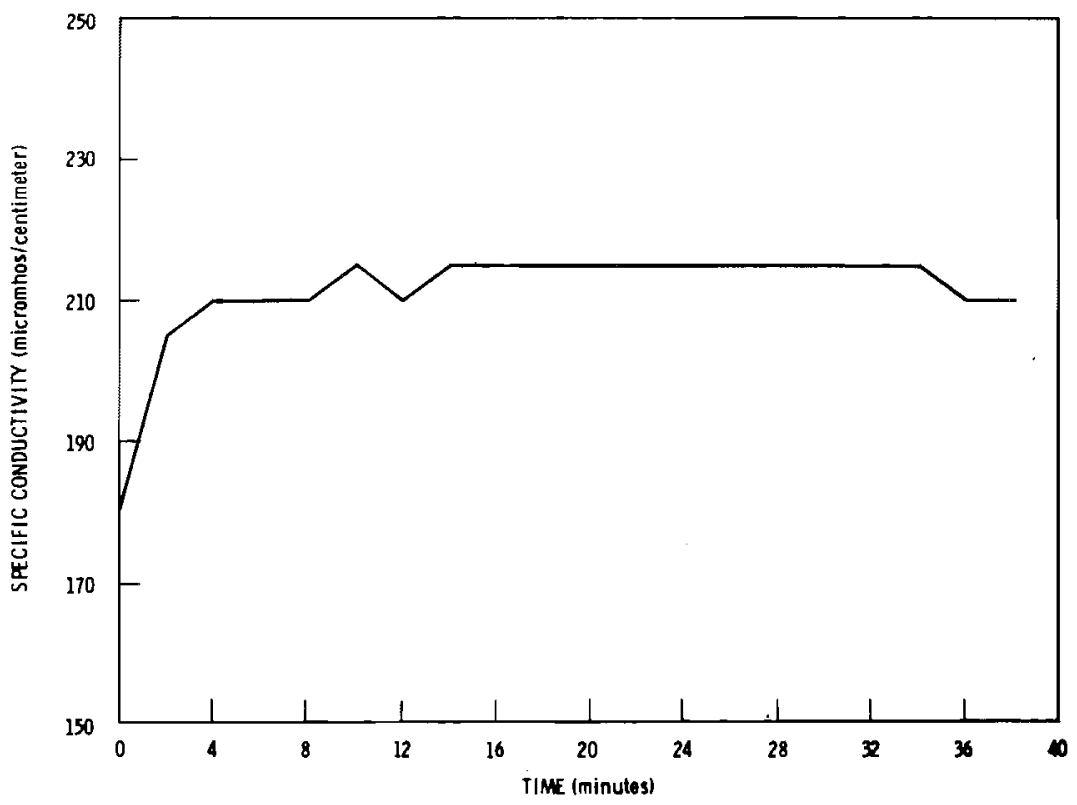

FIGURE B.7. Specific Conductivity vs. Pumping Time in We11 699-55-50C

B. 5 
APPENDIX C 


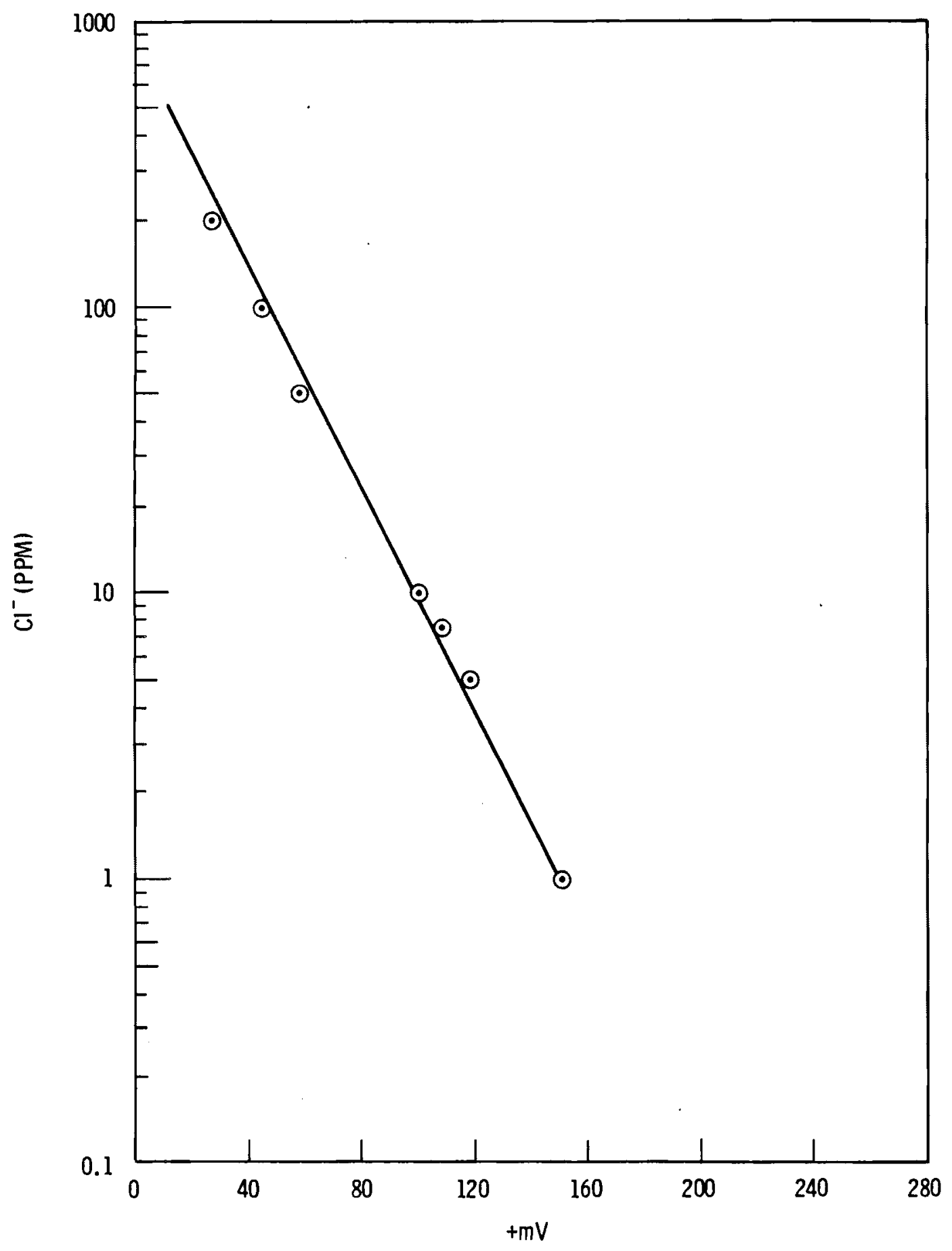

FIGURE C.1. Chloride Standard Curve

C.1 


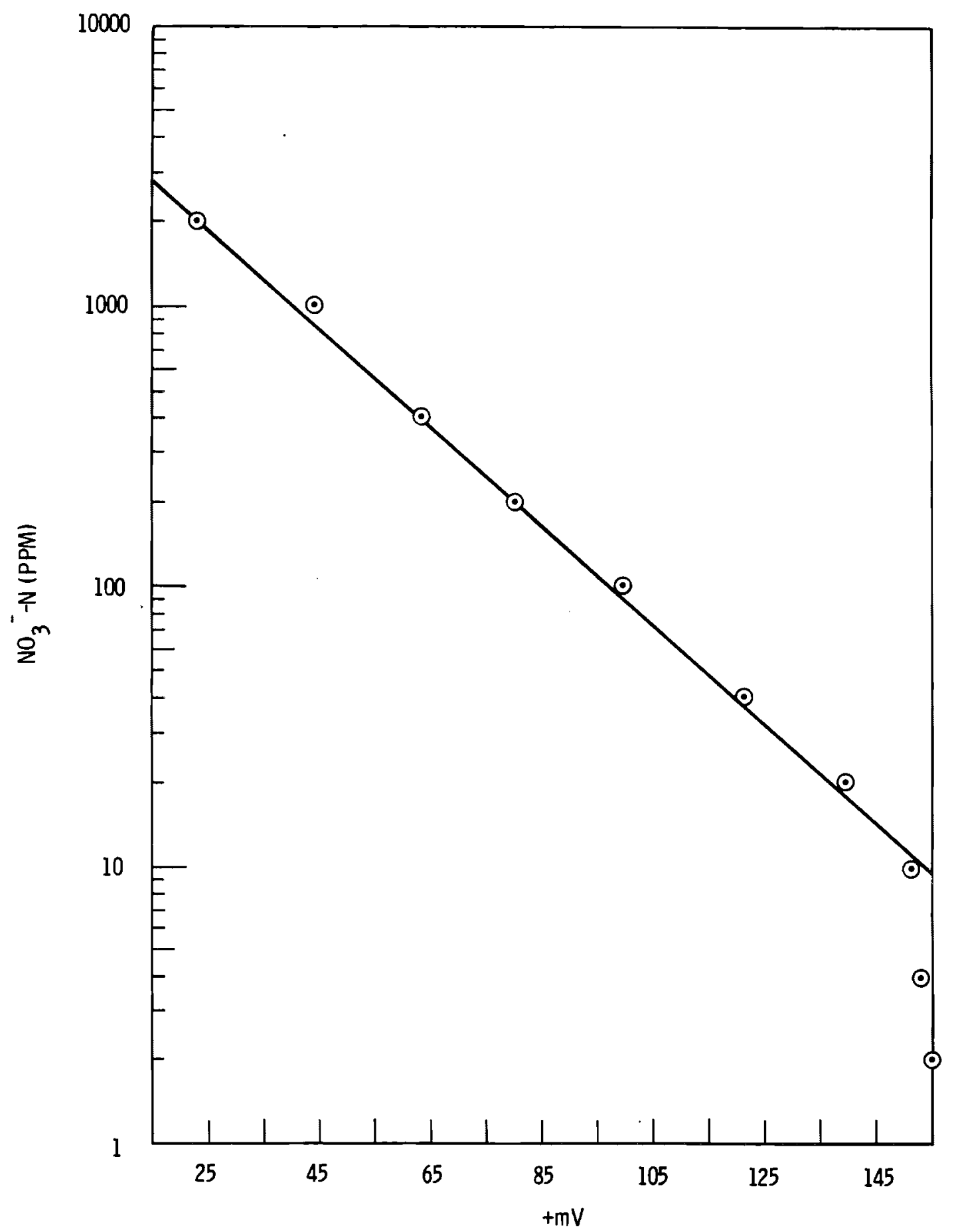

FIGURE C.2. Nitrate Standard Curve 


\section{DISTRIBUTION}

No. of

Copies

OFFSITE

A. A. Churm

DOE Patent Division

9800 South Cass Avenue

Argonne, IL 60439

S. R. Arlt

City of Richland

Water and Sewer Department

P.0. Box 190

Richland, WA 99352

H. L. Cahn

Benton-Franklin District Health Department

506 McKenzie

Richland, WA 99352

D. E. Clark

Exxon Nuclear

Horn Rapids Road

Richland, WA 99352

3 E. Cowan

Environmental Protection Agency Region $X$

1200 6th Avenue/MS-533

Seattle, WA 98101

2 G. W. Cunningham

DOE Office of Waste Management, Production and Reprocessing Washington, DC 20545

27 DOE Technical Information Center

S. R. Elliott

DOE Office of Safety and Health P.0. Box 14100

Las Vegas, NV 89114
No. of

Copies

$\underline{\text { OFFSITE }}$

R. H. Engleken

NRC Regional Administrator

1450 Marie Lane

Walnut Creek, CA 94596

G. Facer/DP-29

DOE Office of Military

Application

Washington, DC 20545

G. L. Fiedler

Washington State Department of Ecology

MS PV-11

01 ympia, WA 98503

M. 0. Fretwel 1

Water Resources Division

U.S. Geological Survey

345 Middlefield Road

Men lo Park, CA 94025

J. D. Griffith

DOE Office of Light Water

Reactors

NE-550

Washington, DC 20545

Fred Hahn

Washington State Department of Ecology

MS PV-11

01ympia, WA 98504

W. A. Kiel

Washington Public Power Supply System

P.0. Box 968 MS 540

Richland, WA 99352 
No. of

Copies

OFFSITE

N. P. Kirner

Washington State Department of Social and Health Services

MS LD-11

O1ympia, WA 98504

J. N. Kline

U.S. Geological Survey

1201 Pacific Avenue, Suite 600

Tacoma, WA 98402

M. L. Miller

Washington Public Power Supply System

P.0. Box 968 MS 540

Richland, WA 99352

R. R. Mooney

Washington State Department of

Social and Health Services

1409 Smith Towers

Seattle, WA 98104

D. W. Moos

Washington State Department of Ecology

O1ympia, WA 98504

G. G. Outterson

Section 556

Battelle Memorial Institute

505 King Avenue

Columbus, $\mathrm{OH} 43201$

R. D. Paris

Oregon State Health Division

1400 S.W. Fifth Avenue

Portland, OR 97201

M. W. Parrott

Radiation Control Section

Oregon State Health Division

P.0. Box 231

Portland, OR 97207
No. of

Copies

OFFSITE

4

D. E. Patterson/EP-13

DOE Office of Operational and Environmental Safety

Washington, DC 20545

J. B. Robertson

U.S. Geological Survey

MS -410

Reston, VA 22092

L. Rocha

Oregon State Health Division

1400 S.W. Fifth Avenue

Portland, OR 97201

Harold L. Sawyer

Administrator of Water Quality

Oregon State Department of

Environmental Quality

P.0. Box 1760

Portland, OR 97205

D. A. Stewart-Smith

Oregon State Health Division

1400 S.W. Fifth Avenue

Portland, OR 97207

T. Strong

Washington State Department of

Social and Health Services

MS LD-13

O1ympia, WA 98504

G. Toombs

Oregon State Health Division

P.0. Box 231

Portland, OR 97207

Washington State Department of Ecology

Library

Olympia, WA 98503 
No. of

Copies

$\underline{\text { OFFSITE }}$

C. G. Welty/EP-133

DOE Office of Operational and Environmental Safety

Washington, DC 20545

ONSITE

18 DOE Richland Operations Office

R. E. Austin (5)

G. D. Bouchey

C. S. Carlisle

0. J. Elgert (2)

D. R. Elle (5)

R. E. Gerton

H. E. Ransom

J. L. Rhoades

M. W. Tiernan

2 Hanford Environmental Health Foundation

L. J. Maas

B. D. Reinart

9 Rockwell Hanford Operations

M. J. Graham (2)

G. L. Hanson

A. G. Law

M. M. McCarthy

W. H. Price

B. J. Saueressig

J. S. Wilbur

RHO File

6 United Nuclear Corporation

P. A. Carlson

E. M. Greager

A. P. Vinther

E. A. Weakley

W. G. Westover

UNC File
No. of

Copies

ONSITE

3 Westinghouse Hanford Company

R. 0. Budd

G. Carpenter

R. B. Hall

$46 \quad$ Pacific Northwest Laboratory

P. J. Blumer

P. E. Bramson

C. S. Cline

P. A. Eddy

E. L. Hilty

H. V. Larson

V. L. McGhan

L. S. Prater (15)

M. R. Quarders (15)

J. T. Rieger

Technical Information (5)

P. E. Bramson--Historical File Publishing Coordination (2) 


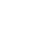

